\title{
ALAT-ALAT BATU PACITAN: MOBILITAS BUDAYA PRASEJARAH
}

\section{Oleh: Harry Widianto}

Dalam kerangka periode prasejarah di Indonesia, masa berburu dan mengumpulkan makanan tingkat sederhana dengan penonjolan tradisi paleolithik telah menempati posisi yang tertua. Masa ini bermula dengan terciptanya hasil-hasil kebudayaan manusia pertama sekitar 700.000 tahun yang lalu, kemudian berakhir pada awal Kala Holosen, sekitar 10.000 tahun silam. Dari jangka waktu itu, berbagai alat untuk mengeksploitasi lingkungan telah menjadi bukti tentang eksistensi pendukung kebudayaan Kala Plestosen di Indonesia. Betapapun sangat sederhananya, alat-alat ini telah memberikan gambaran tentang perilaku manusia Plestosen di Indonesia, terutama tentang hubungan timbal-balik yang erat antara lingkungan hidup manusia, teknologi dan sistem-sistem sosial. Tiap-tiap gejala ini harus diperhatikan secara seksama, sehingga dapat diketahui hubungan fungsionalnya.

Dalam usaha untuk mengetahui pola hidup manusia prasejarah di Indonesia, suatu studi terhadap alat-alat batu telah kami lakukan di S. Baksoka, Kecamatan Punung, Kabupaten Pacitan, Propinsi Jawa Timur. Penelitian dilakukan dengan menyusur sungai sejauh $\pm 2 \mathrm{~km}$, yang meliputi dukuh Dung Jangan dan dukuh Kladen (Kalurahan Sooka); dukuh Kalipucung dan dukuh Pagutan (Kalurahan Punung) serta dukuh Nglebeng, Nampol dan Ngrejo (Kalurahan Mendolo Kidul). Pengambilan sampel alatalat batu, baik yang berupa alat batu masip maupun serpih dan bilah, serta pendokumentasian keadaan lingkungan dan temuan merupakan cara yang diambil dalam penelitian ini. Dari data tersebut di atas, diharapkan perkembangan teknologi alat-alat batu sebagai tujuan dalam penelitian ini dapat diketahui.

Sungai Baksoka merupakan sungai terbesar di Kecamatan Punung. Di musim kemarau, air sungai ini surut hingga dasar sungai, sedangkan pada musim hujan, air mencapai ketinggian 2-3 meter dari dasar sungai. Penemuan alat-alat batu banyak dihasilkan oleh adanya pengikisan air terhadap dinding sungai dan permukaan tanah, baik oleh arus sungai maupun oleh air hujan. Materi tanah pada daerah ini sebagian besar berupa tanah gamping putih kekuningan. Pada kedalaman rata-rata 1 meter dari permukaan tanah, secara umum berupa tanah gembur yang berwarna coklat kemerahan, yang merupakan hasil pelapukan batu gamping yang di beberapa bagian masih melekat di atas batuan induknya.

Dilihat dari singkapan di sepanjang sungai yang menunjukkan ciriciri yang sama, tampaknya tebing sungai ini dihasilkan oleh adanya pengangkatan tanah yang kemudian ditoreh oleh air sungai. Tenaga arus sungai lebih besar bila dibandingkan dengan pengangkatan yang terjadi; sehingga menyebabkan lapisan-lapisan yang berumur tua membentuk tebing sungai dan dataran di sekitarnya. Kemudian disusul dengan erosi, yang menyebabkan lapisan tanah di daerah ini berupa tanah dengan umur tua. 


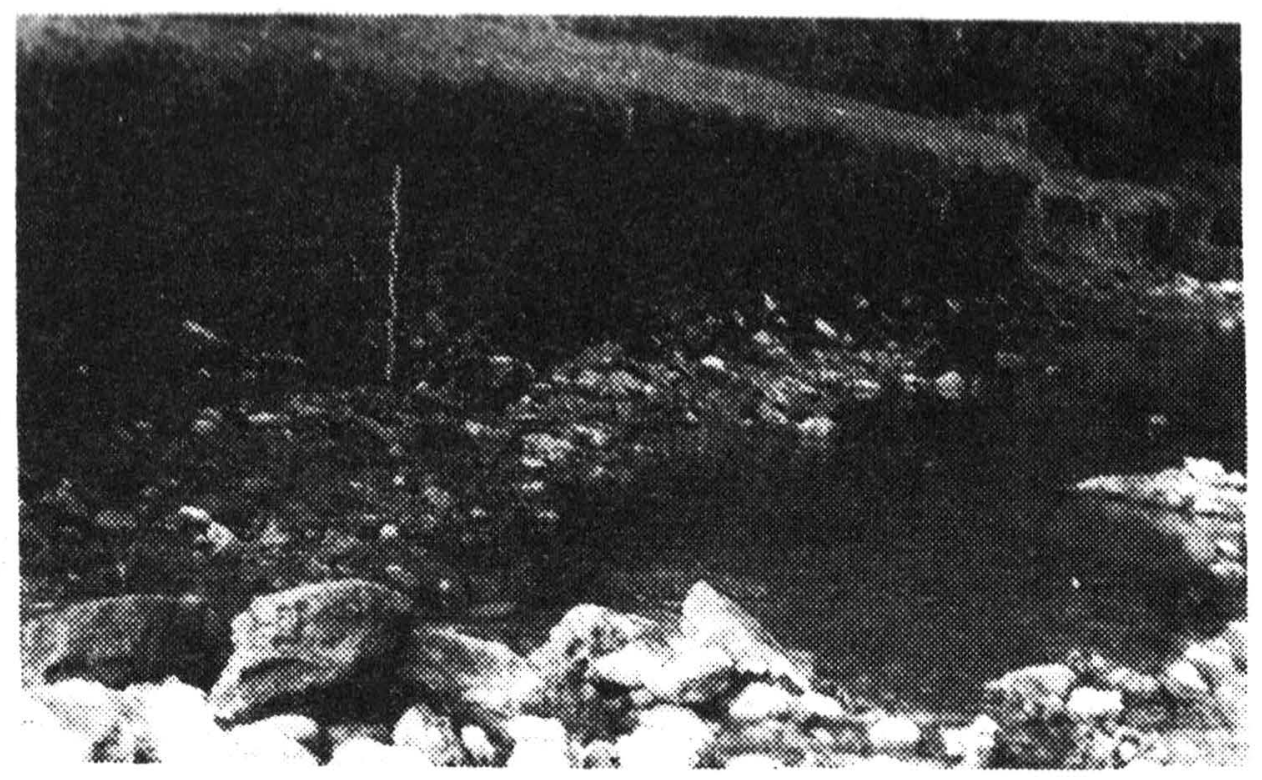

Stratigrafi di sepanjang Sungai Baksoka. Lapisan berbatu merupakan konglomerat bongkah, mengandung alat-alat paleolitik.

Daerah penelitian menunjukkan perlapisan tanah yang ideal, yang dapat dibedakan secara tegas ke dalam 3 Horison, yaitu Horison A (Zone of leaching), Horison B (Intermidiate zone) dan Horison C (Bed-rock) (Foto: 1). Setiap horison dapat dibedakan berdasarkan warna, jenis maupun ukuran batuan. Pembagian 3 horison tersebut merupakan ciri tanah yang telah dewasa (Soetoto, 1980: 16).

Sehubungan dengan alat-alat paleolitik di situs ini, maka Horison B merupakan lapisan terpenting. Lapisan ini terletak di bagian tengah, dengan ketebalan rata-rata 1,50 meter. Keletakannya tidak horisontal, kadang-kadang terletak di atas batuan gamping dan di lain tempat menghilang di dasar sungai. Horison ini merupakan konglomerat bongkah dengan inti batu berukuran kerikil halus hingga kasar. Di beberapa tebing, terutama di kalurahan Mendolo Kidul, ketebalannya mencapai 4-5 meter. Alat-alat paleolitik terkonsentrasi pada lapisan ini, sehingga lapisan tersebut dapat dianggap sebagai lapisan budaya. Materi tanah di bagian bawah lapisan merupakan hasil pelapukan membola (spheroidal-weathering) batu batu andesit yag menyusun lapisan ini. Hal ini diperlihatkan oleh adanya lapukan batu yang menyelubungi inti batu.

Sebagian besar alat-alat batu yang ditemukan di situs ini berasal dari dasar sungai, kemungkinan berasal dari Horison B pada dinding sungai. Oleh karenanya, alat-alat ini merupakan bagian dari endapan alluvial, terutama yang bersifat sedimen klastik.

Pendapat tersebut di atas diperkuat oleh adanya proses pembulatan (rounded) pada sudut-sudut pemangkasan alat.

Selama 3 hari penelitian di situs ini, telah berhasil dikumpulkan alatalat yang berupa alat batu masip, serpih, bilah, alat dari fosil kayu dan sebuah fosil kerang. Selain fosil kerang, alat-alat tersebut dapat diperinci se- 
bagai berikut: 15 buah kapak perimbas, 3 buah kapak penetak, 1 buah proto kapak genggam, 2 buah kapak genggam, 7 buah kapak persegi neolitik, 7 buah serpih, 1 buah bilah dan 1 buah alat dari fosil kayu. Secara umum alatalat tersebut dibuat dari batu gamping kersikan (Silicified-limestone) dan tufa kersikan (silicified tuff) yang merupakan hasil letusan gunung berapi. Warna putih keruh mengarah ke coklat muda merupakan ciri batu gamping kersikan, sedangkan tufa kersikan umumnya berwarna coklat tua hingga coklat kehitaman (Heekeren, 1972: 35). Sebuah proto kapak genggam yang ditemukan di dukuh Ngrejo masih melekat pada dinding tebing sungai, terletak pada lapisan konglomerat bongkah (Foto: 2). Alat ini hampir berbentuk segitiga, dengan salah satu sisinya agak melengkung (Foto: 3 ). Selain temuan tersebut, seluruh temuan berasal dari dasar sungai. Kemungkinan alatalat ini telah mengalami transportasi dari daerah asalnya.

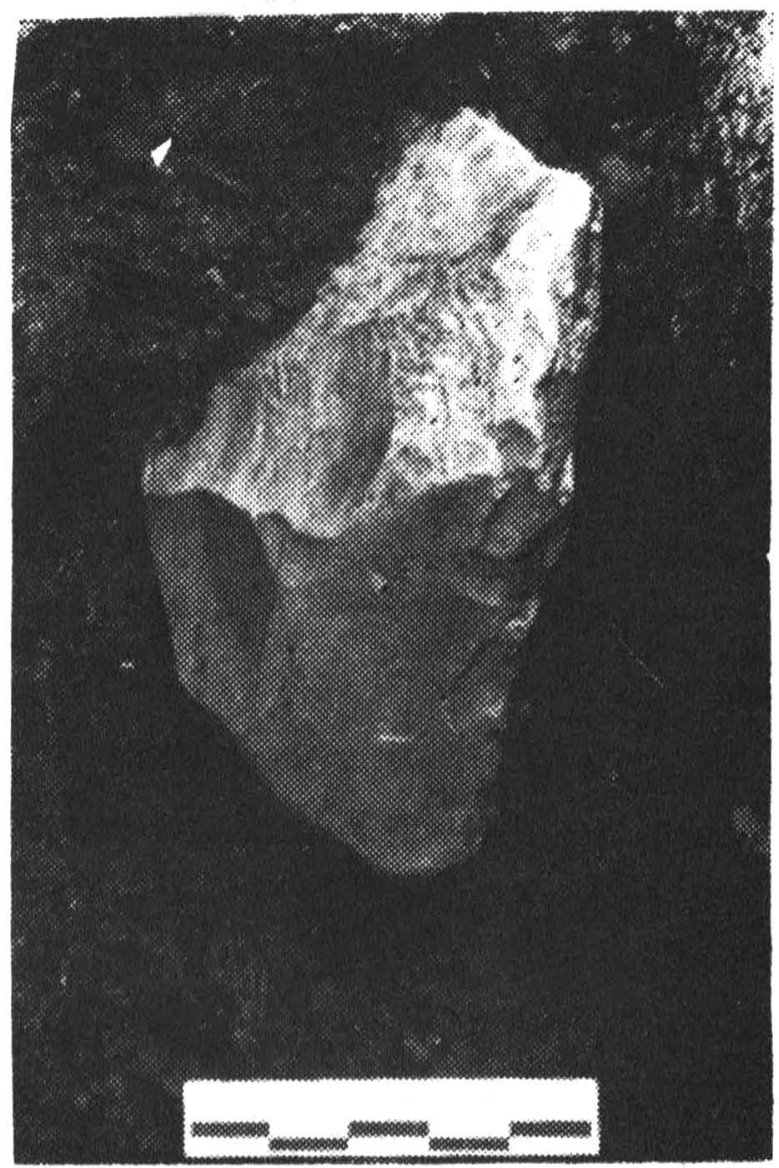

Sebuah proto kapak genggam yang masih mele|kat pada dinding tebing di Dukuh Ngrejo, Kalu rahan Mendolo Kidul.

Alat-alat kapak penetak dan perimbas sebagian besar masih mengandung kulit batu. Hal ini memberikan gambaran bahwa alat ini mengalami pemangkasan langsung untuk mendapatkan bagian tajaman, yaitu dengan membenturkan ke batu lain. Dalam usaha pembentukan bagian tajaman tersebut, kapak perimbas dipangkas secara monofasial, yang biasanya dibentuk bundar, semi oval maupun lurus. Sedangkan kapak penetak, pemangkasan dilakukan secara bifasial. Kadang-kadang dilakukan pemangkasan silang-siur, sehingga akan menghasilkan bagian tajaman yang membentuk huruf $W$ yang melebar. 
Bentuk-bentuk khusus dari kapak perimbas dan penetak adalah kapak genggam yang benar-benar telah dipangkas secara menyeluruh di semua bagian. Menurut Movius, kapak genggam Pacitan merupakan perkembangan lanjut dari kapak penetak (Bartstra, 1976: 78). Ciri utamanya adalah pemangkasan silang-siur (criss-cross chipping).

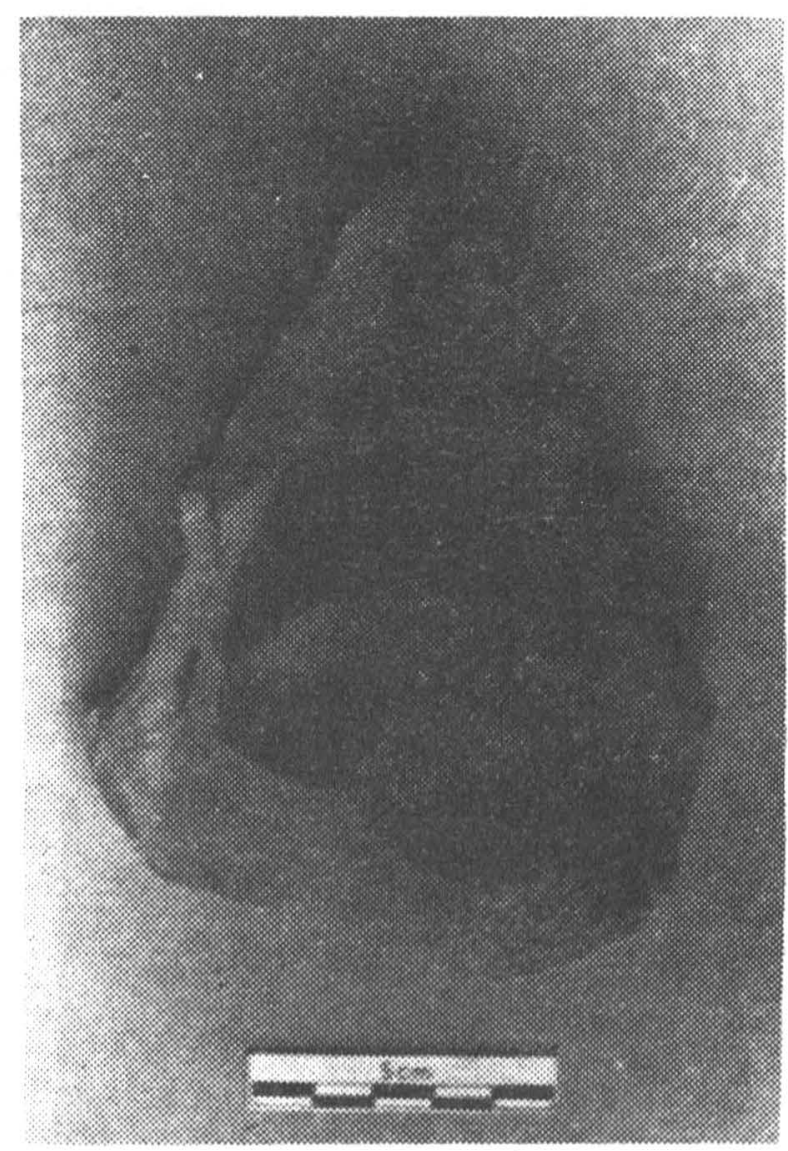

Detil temuan proto kapak genggam.

Dua buah kapak genggam yang ditemukan masing-masing berasal dari dukuh Nglebeng dan dukuh Kalipucung. Pemangkasannya kelihatan tegas, sedangkan proses pemt ndaran belum begitu lanjut (Foto: 4).

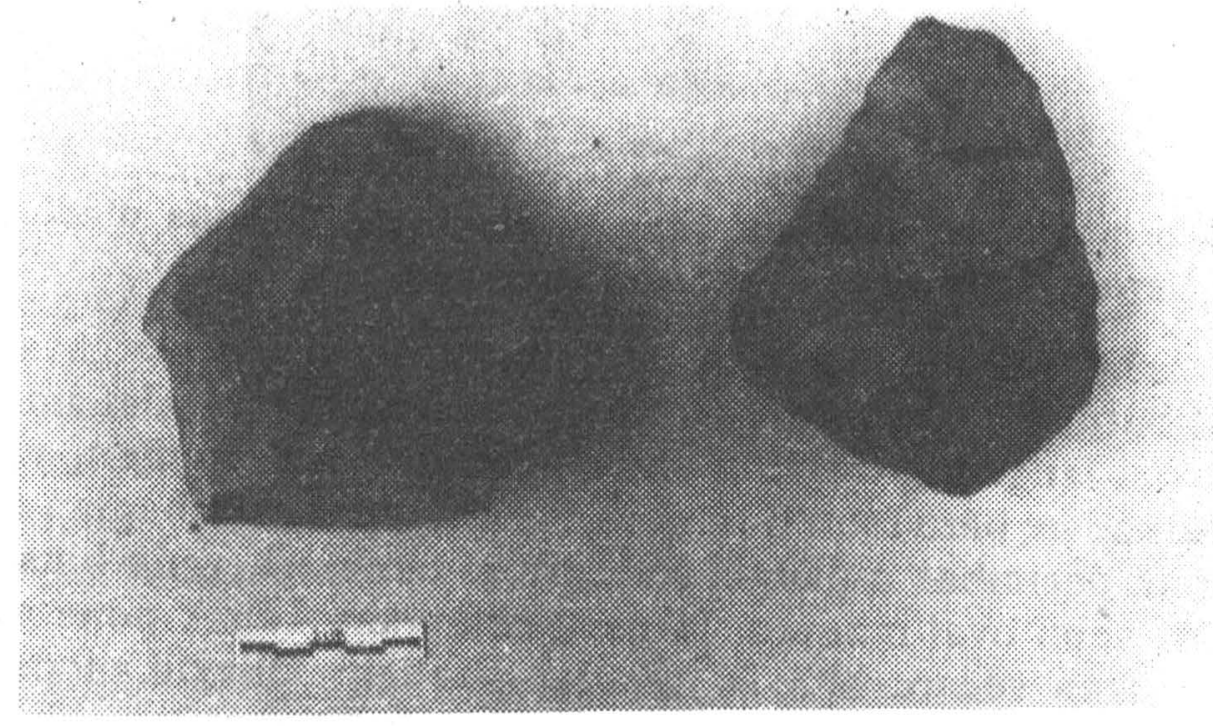

Dua buah kapak genggam dari Dukuh Kalipucung dan Dukuh Nglebang. 
Di samping alat-alat batu masip, serpih dan bilah juga ditemukan. Alatalat serpih dihasilkan dari kegiatan pembuatan alat batu masip. Alat ini biasanya berukuran kecil. Selain itu ada pula alat-alat serpih yang khusus dipersiapkan ke dalam bentuk-bentuk alat secara teliti, sebelum dilepaskan dari batu intinya.

Kadang-kadang akan menampakkan faset-faset di dataran pukulnya (Soejono, 1975: 101). Serpih-serpih yang dibuat manusia, akan memperlihatkan ciri-ciri khusus yaitu: dataran pukul (striking-platform), kerucut pukul (bulb of percussion), tatu serpih (bulbar scar), alur serpih (ripples) dan celah serpih (fissures) (Oakley, 1972: 10). Dala m hal ini, batu inti dapat dikatakan merupakan sumber alat serpih sampai ukuran terkecil. Sebuah bilah yang ditemukan mempunyai bentuk memanjang, dengan penampang segitiga, panjang $7,6 \mathrm{Cm}$. Berdasarkan bentuknya yang memanjang, maka bilah ini diperkirakan berfungsi sebagai alat penusuk.

Selain alat tersebut di atas, menarik perhatian pula penemuan kapak-. kapak persegi neolithik yang belum diupam, di tengah-tengah hasil perbengkelan alat-alat paleolithik. Kedua hasil kebudayaan ini sangat jauh berbeda, baik dari jangka waktu maupun corak kehidupannya. Paleolithik Pacitan diperkirakan sedikitnya berumur 100.000 tahun yang dihasilkan dari corak kehidupan berburu dan mengumpul makanan tingkat sederhana. Di lain pihak, alat-alat neolithik paling tua berumur 7000 tahun, dengan corak kehidupan bercocok tanam. Kedua hasil kebudayaan ini berbaur menjadi satu di dasar sungai Baksoka, setelah keduanya ditransportasikan dari lokasi aslinya. Alat-alat paleolithik kelihatan lebih mendominasi kawasan ini.

Sehubungan dengan temuan tadi, Von Heine Geldern menyebutkan bahwa di sepanjang pegunungan kapur di Jawa Tengah dan Jawa Timur bagian selatan, terdapat lebih dari 100 perbengkelan neolithik. Salah satunya ditunjuk daerah Punung dan sekitar Pacitan. Perbengkelan ini ditemukan oleh Van Stein Callenfels pada tahun 1927 (Geldern, 1945: 136). Perbengkelan serupa juga ditemukan di Wonogiri dan di Bagogoh-Bogor.

Dari beberapa pembicaraan di atas, terdapat suatu gambaran bahwa situs Punung merupakan salah satu situs terpenting di Indonesia yang sanggup memberikan data tentang proses kehidupan manusia Plestosen secara lengkap. Segala unsur kegiatan manusia Plestosen yang ditinggalkan berupa kapak perimbas, kapak penetak, kapak genggam serta serpih dan bilah ditemukan di sini secara melimpah.

Tidak saja hasil-hasil kebudayaan dari Kala Plestosen yang ditemukan, tetapi juga ditemukan alat-alat neolithik yang berupa kapak persegi setengah jadi dari masa bercocok tanam dalam Kala Holosen.

Van Heine Geldern menunjuk bahwa situs ini merupakan situs perbengkelan neolithik yang banyak terdapat di sepanjang Pegunungan Sewu di Jawa Tengah dan Jawa Timur.

Potensi paleolithik di Punung diketahui mulai tahun 1935.

Pada saat itu, GHR von Koenigswald dan W.M.F Tweedie melakukan perjalanan di sekitar Pegunungan Sewu di Jawa Timur untuk membuktikan ada nya informasi tentang artefak-artefak neolithik yang diberikan oleh Van Stein Callenfels. Pada saat keduanya menyeberangi dasar sungai Baksoka yang 
kering, mereka menemukan beberapa kapak genggam. Penemuan tersebut kemudian diterbitkan oleh Koenigswad pada tahun 1936. Setelah itu, akhliakhli dari berbagai disiplin ilmu meneliti situs ini, antara lain: Tielhard de Chardin, de Terra, Movius, van Bemmelen, H.R van Heekeren, S. Sartono, R.P Soejono dan T. Jacob. Penelitian terakhir dilakukan oleh Gert Jan Bartstra dan hasil-hasilnya dituangkan dalam bentuk desertasi dengan judul: Contributions to the Study of the Palaeolithic Patjitan Culture Java, Indonesia, yang diterbitkan pada tahun 1976.

Berbagai sumbangan penelitian tadi sesungguhnya telah melengkapi data tentang paleolithik dan lebih memantapkan kedudukan situs Punung dalam kerangka kronologi Plestosen di Indonesia.

Terhadap temuan di sini, Koenigswald telah memasukkan kapak genggam Pacitan sebagai alat paleolithik yang bercorak Chellan, suatu tradisi yang berkembang pada tingkat awal paleolithik Eropa (Bartstra, 1976: 76). Alatalat ini bagian dasarnya biasa dikerjakan secara bilateral, dengan lancipan yang dibentuk melalui penyerpihan. Baik alat-alat batu masip maupun serpih dan bilah, dibuat dari batu gamping kersikan dan tufa kersikan.

Penerapan teknologi batu terhadap alat-alat Pacitan telah melahirkan gagasan di benak Movius untuk mengadakan pen-tipe-an alat-alat ini ke dalam: kapak perimbas (chopper), kapak penetak (chopping-tool), pahat genggam (hand-adze) dan proto kapak genggam (proto hand-axe). Berdasar kan persamaan corak dengan alat-alat yang ditemukan di Birma, Malaysia, Pakistan dan Cina, maka Movius menolak gagasan Koenigswald yang memasukkan alat-alat ini ke dalam tipe-tipe paleolithik Eropa, tetapi merupakan salah satu corak perkembangan kapak perimbas di Asia Timur (Soejono, 1980: 40).

Dalam penelitian terhadap situs yang sama, beberapa kapak perimbas ditemukan oleh H.R van Heekeren, P. Mark, R.P Soejono dan Basoeki pada tahun 1953. Van Heekeren setuju dengan pembagian tipologi Movius, tetapi kemudian ia membagi lagi kapak perimbas ke dalam 4 tipe khusus, yaitu tipe telapak kuda (horse-hoof), setrika (flat-iron), serut dasar (end-chopper) dan serut samping (side-chopper) (Heekeren, 1972: 40). Tipe setrika dan tipe telapak kuda merupakan corak khusus industri Pacitan. Melihat kesebandingan dengan teknik-teknik yang ditemukan di beberapa negara Asia lainnya, maka Van Heekeren memasukkan alat-alat Pacitan ke dalam teknik chopper-choopping tool complex yang berkembang di Asia Tenggara (Heekeren, 1972: 39).

Menurut Koenigswald, usia alat-alat Pacitan dinyatakan tidak lebih muda dari Kala Plestosen Tengah (Soejono, 1980: 44). Kesimpulan ini didasarkan pada lokasi penemuan alat-alat tersebut yang terletak pada lapisan konglomerat bongkah pada Horison B. Dari penelitian geologis, lapisan ini terbentuk karena pelipatan yang umumnya terjadi pada Kala Plestosen Tengah di Jawa, yang salah satunya tersingkap di Sungai Baksoka. Alatalat ini ikut terlipat di dalamnya, sehingga paling tidak, sebelum terjadi pe- 
lipatan alat ini sudah diendapkan. Hal tersebut memberikan arti bahwa umur alat ini paling muda adalah Plestosen Tengah.

Suatu hal yang masih dipermasalahkan terhadap situs ini adalah tentang pendukung kebudayaan Pacitan itu sendiri. Penemuan fosil manusia yang dapat dikaitkan dengan kebudayaan Pacitan masih belum ada. Penelitian oleh $\mathrm{T}$. Jacob di masa lalu hanya menghasilkan fosil binatang vertebrata. Suatu kenyataan yang mengherankan: suatu konsentrasi alat paleolithik yang melimpah, tanpa indikasi sedikitpun tentang pendukungnya dalam asosiasi yang jelas! Undak-undak sungai Baksoka yang terbentuk pada bagian akhir Kala Plestosen Tengah mungkin telah menjadi lokasi pendirian kemah manusia paleolithik (Soejono, 1975: 87). Kegiatan arus sungai terhadap . undak-undak di sekitarnya! kemungkinan besar telah memisahkan manusia dan budayanya. Dengan demikian, sumber dari alat-alat paleolitik jan pendukungnya harus dicari ke arah hulu, karena lokasi penemuan saat lini merupakan lokasi sekunder, yaitu hasil transportasi.

Atau kemungkinan lain, jenis tanah setempat tidak memenuhi syarat proses fosilisasi suatu tulang atau benda lainnya.

Suatu titik terang bagi pendukung kebudayaan yang sangat kabur ini datang dari penemuan di kawasan Asia Timur, yaitu gua Chou-Kou-Tien dekat Peking. Di gua ini, Davidson Black menemukan fosil Pithecanthropus pekinensis, sùatu makhluk yang sejenis dengan Pithecanthropus erectus, beserta alat-alat berupa kapak penetak dan perimbas yang menyerupai benar dengan alat-alat Pacitan, dalam konteks yang sangat jelas. Selain itu ditemukan pula tulang-tulang sisa makanan yang hangus terbakar. Hal ini membuktikan bahwa Pithecanthropus pekinensis telah mengenal api. Selama 10 tahun penggalian di gua ini telah menghasilkan tidak kurang dari 45 individu dengan alat yang melimpah.

Melalui analogi dengan temuan di Cina tadi, gambaran kabur mengenai industri Pacitan mulai menampakkan titik-titik terang.

Alat-alat Pacitan sejenis dengan artefak-artefak dari Cina, terutama dari tipologi maupun teknologinya. Di lain pihak, temuan di Cina tadi berasosiasi langsung dengan fosil Pithrecanthropus pekinensis. Fosil ini di Indonesia telah ditemukan di undakan teras sepanjang Bengawan Solo, terutama di Trinil, Ngandong dan Sangiran. Berdasarkan data di atas, kiranya tidak terlalu:jauh menyimpang seandainya pendukung alat-alat Pacitan adalah Pithecanthropus erectus.

Suatu masalah yang kemudian muncul adalah terpisahnya lokasi penemuan antara manusia dengan hasil-hasil kebudayaran. Penelitian geologis diharapkan dapat memecahkan masalah ini secara lebih jelas.

Dari hasil temuan dalam penelitian selama ini, jelas sekali bahwa faktor serpih dan bilah sama-sama penting peranannya dengan alat-alat batu masip. Pada masa selanjutnya, yaitu masa berburu dan mengumpulkan makanan tingkat lanjut (mesolithik), terjadi suatu perubahan drastis, yaitu serpih dan bilah jauh lebih dominan dibandingkan dengan alat batu masip. Keadaan ini mungkin disebabkan oleh perubahan yang sangat menyolok ter- 
hadap sumber-sumber makanan mereka, terutama binatang buruannya. Melimpahnya alat batu masip serta serpih dan bilah pada masa berburu dan mengumpulkan makanan tingkat sederhana (paleolithik), menimbulkan gambaran bahwa alat-alatnya lebih sesuai untuk melakukan pekerjaan berat. Pada masa tersebut, binatang buruan merupakan binatang besar, antara lain: Stegodon trigonocephallus, Hippopotamus antiqunus, Cervus lydekkeri dan Duboisia kroesenii (Clark, 1972: 89; cf. Soejono, 1975: 108; Hutterer, 1977: 40; Bartstra, 1976: 109). Binatang-binatang tersebut berasosiasi langsung dengan fosil Pithecanthropus erectus yang ditemukan oleh Dubois pada tahun 1892 di Trinil, dekat Ngawi (Hoop, 1938: 13).

Menurut Le Gros Clark, binatang-binatang tersebut hidup pada Kala Plestosen Tengah, mungkin terbentuk pada glasiasi kedua dari jaman es yang berlangsung di beberapa bagian dunia.

Pada masa selanjutnya, yaitu masa berburu dan mengumpul makanan tingkat lanjut (mesolithik), alat-alat yang berukuran kecil merupakan faktor dominan. Gejala yang menunjukkan perkembangan ini terutama ditemukan pada konteks peralatan Toala, yang banyak menghasilkan mikrolit, mata panah bersayap atau bergerigi, serpih dan bilah bergerigi, lancipan tebal sesisi dan lancipan Muduk. Alat-alat tersebut menunjukkan kegiatan perburuan terhadap hewan-hewan kecil (Soejono, 1975: 148). Menghadapi kenyataan tersebut, terdapat beberapa hal yang mungkin dapat dijadikan faktor penyebab bagi perubahan penonjolan alat pada kedua masa tersebut, yaitu:

1. pada masa berburu dan mengumpul makanan tingkat sederhana (paleolithik), corak kehidupan lebih dipusatkan pada perburuan binatang besar, karena binatang ini masih dominan. Di lain pihak, perburuan binatang kecil dan pengumpulan makanan dari tumbuh-tumbuhan masih belum dirasa keperluannya bagi kelangsungan hidup mereka.

2. Adanya perubahan iklim yang disebabkan oleh berakhirnya masa glasial keempat. Semua daratan yang tadinya terbentuk karena turunnya air laut, kemudian tertutup kembali oleh air laut, termasuk Paparan Sunda dan Paparan Sahul. Akibatnya, hewan-hewan besar yang semula hidup bebas bergerak dengan sumber makanan melimpah, kemudian terpencil di lingkungan yang lebih sempit dan hidup dari sumber makanan yang terbatas. Selanjutnya, terjadilah pengecilan di kalangan fauna, yaitu binatang besar berevolusi ke ukuran yang lebih kecil.

3. Pada masa mesolithik, corak kehidupan lebih dipusatkan pada perburuan binatang kecil dan binatang air (aquatic animal).

Hal ini dibuktikan dengan munculnya alat-alat serut dari kulit kerang, mata panah bergerigi, tombak ikan dan adanya temuan bukit kerang (kyokkenmodinger) di Sumatra Utara. Bukit ini merupakan tumpukan kulit kerang sisa makanan. Selain itu, pengumpulan makanan dengan bercocok tanam secara sederhana juga merupakan kegiatan pokok mereka. Pekerjaan ini dilakukan dengan cara berpindah-pindah, menurut kesuburan tanah. Pada masa berikutnya, corak kehidupan telah bertumpu pada pola bercocok tanam.

Faktor-faktor di atas sesungguhnya telah memberikan gambaran tentang mekanisma dan mobilitas dari masyarakat jaman batu, yang juga ber- 
laku terhadap situs Punung ini. terutama sekali digunakan untuk an yang berupa daging binatang hasilkan oleh masyarakat pemburu Berbagai alat yang ditemukan di situs ini pencarian dan pengolahan bahan makandan umbi-umbian. Alat-alat batu yang diakan menunjukkan beberapa kekhasan dan perbedaan dengan hasil masyarakat yang telah menetap maupun masyarakat petani.

Segala bentuk alat-alat batu dapat dipelajari sejak pembuatannya yang mula mula sekali, sehingga perkembangan teknik pembuatannya dapat diikuti secara seksama.

Dengan mempelajari teknik-teknik alat batu, maka mobilitas budaya prasejarah situs ini dapat dipelajari. Gerakan-gerakan pendukungnya, terutama dalam perubahan sasaran makanan, telah dimanifestasikan ke dalam bentuk dan ukuran alat. Masyarakat paleolithik lebih menitikberatkan pola kehidupan pada perburuan binatang besar, masyarakat mesolithik pada perburuan binatang kecil dan masyarakat neolithik menitikberatkan kehidupan pada pola bercocok tanam. Mobilitas tersebut telah menunjukkan kemampuan manusia dalam memanfaatkan bahan-bahan makanan yang disediakan oleh alam. Usaha pokok manusia adalah memilih alternatip tentang caracara dan upaya manusia untuk dapat mempertahankan kehidupannya, yang selanjutnya dikembangkan dalam segi kehidupan sosial dan ekonominya.

Gerakan-gerakan kehidupan yang dicerminkan oleh alat-alat batu, terutama sekali disebabkan oleh perubahan sasaran sumber makanan. Evolusi ukuran binatang, dari ukuran besar pada Kala Plestosen ke ukuran kecil pada Kala Holosen, telah memaksa masyarakat paleolithik untuk menciptakan alat-alat masip dan menggerakkan masyarakat mesolithik menciptakan alat-alat yang berukuran kecil. Evolusi di kalangan fauna tersebut terutama sekali disebabkan oleh berakhirnya masa glasial keempat pada awal Kala Pos Plestosen. Iklim yang liar selanjutnya digantikan oleh iklim yang tenang.

Dengan disertai bertambahnya tingkat kecerdasan manusia, kebutuhan tentang hari esok mulai dipikirkan. Pola perburuan binatang dan pengumpul an makanan mulai ditinggalkan dan muncullah ide-ide di kalangan masyarakat neolithik untuk mengolah bahan makanan melalui bercocok tanam. Suat u mobilitas kebudayaan kembali dicatat, yaitu munculnya alat-alat kapak persegi sebagai alat pertanian. Berbagai gejala perubahan dan gerakan seperti ini sangat terasa dalam konteks alat-alat batu Pacitan. Temuan di situs ini meliputi masa berburu dan mengumpul makanan tingkat sederhana hingga masa bercocok tanam. Unsur serpih dan bilah yang ditemukan melimpah pada situs ini mungkin pula sebagian berasal dari masa mesolithik, walaupun belum dapat diidentifikasi secara jelas. Keadaan ini dapat diterima, karena seringkali terjadi bahwa suatu teknologi dari suatu masa akan tetap berlanjut pada masa berikutnya

Berdasarkan uraian di atas, alat-alat batu Pacitan merupakan bukti tentang keanekaragamąn masyarakat yang pernah mendiami daerah ini dan dapat dianggap sebagai salah satu model mobilitas budaya prasejarah. Penelitian lebih mendalam masih sangat diperlukan. Bukan saja bagi penelitian paleolithik, tetapi perlu pula dilakukan penelitian menyeluruh untuk 
memecahkan batas-batas kronologi prasejarah secara lebih jelas. Dengan demikian, akan diperoleh gambaran seutuhnya mengenai situs ini.

$* * * *$

\section{Kepustakaan:}

Bartstra, Gert Jan. Contributions to the Study of the Paleolithic Patjitan 1976 Culture Java, Indonesia. Part 1. Leiden: E. J Brill. Clark, Le Gros. The Fossil Evidence for Human Evolution.

1972 Chicago: University of Chicago Press.

Geldern, R. von Heine. 'Prehictoric Research in the Netherlands Indies',

1945 Science and Scientists in the Netherlands Indies. New York: Board for the Netherlands Indies, Surinam, and Curacao.

Heekeren, H.R. van. 'The Stone Age of Indonesia', Verhandelingen

1972 van het Koninklijk Instituut voor Taal, Land en Volkenkunde. The Hague: Martinus Nijhoff.

Hoop, A.N.J Th a Th. van der. 'De Praehistorie', Geschiedenis van

1938 Nederlandsch Indie I. Amsterdam: N.V Uitgeversmaatschappij. Halaman 7-111.

Huterrer, Karl L. 'Reinterpreting the Southeast Asian Palaeolithic',

1977 Sunda and Sahul: Prehistoric Studies in Southeast Asia, Melanesia and Australia. London, New York, San Francisco.

Oakley, Kenneth P. Man the Tool-maker. Chicago: University of Chicago 1972 Press.

Soejono R.P. 'Penilaian Terhadap Perkembangan Paleolitik di Indone1980 sia', Pertemuan Ilmiah Arkeologi I. Jakarta: Pusat Penelitian Purbakala dan Peninggalan Nasional.

....-.- (editor). Sejarah Nasional Indonesia I.

1975 Jakarta: Balai Pustaka.

Soetoto Tanah Hasil Pelapukan Batuan, Yogyakarta:

1980 Ranggon Studi Heasje Bodni. 